\title{
Scoloplax baskini: a new spiny dwarf catfish from rio Aripuanã, Amazonas, Brazil (Loricarioidei: Scoloplacidae)
}

\author{
Marcelo Salles Rocha, Renildo Ribeiro de Oliveira and Lúcia H. Rapp Py-Daniel
}

A new species of Scoloplax is described from small tributaries of rio Aripuanã, rio Madeira drainage, Amazonas State, Brazil. The new species can be distinguished from its congeners by several morphological features, such as ventral midline plates with two longitudinal parallel rows of odontodes not covered by skin, pectoral and pelvic fins with all rays simple, unbranched, and mesethmoid with a thickened triangular anterior process. Implications of new records of S. dolicholophia from rio Japurá and other comparative features within the genus are discussed.

Uma nova espécie de Scoloplax é descrita para pequenos tributários do rio Aripuanã, drenagem do rio Madeira, estado do Amazonas, Brasil. A nova espécie pode ser diferenciada das demais espécies do gênero por vários aspectos morfológicos, tais como placas ventrais da linha média apresentando duas fileiras paralelas de odontódeos não cobertos por pele, nadadeiras peitoral e pélvica com todos os raios simples, não ramificados, e mesetmóide com um espessamento no processo anterior. Implicações dos novos registros de $S$. dolicholophia do rio Japurá e outros aspectos comparativos do gênero são discutidos.

Key words: Taxonomy, Neotropical, Systematics, Siluriformes.

\section{Introduction}

The neotropical family Scoloplacidae comprises four species of remarkable, small catfishes inhabiting clear and blackwater streams with leaf litter. Species of Scoloplax are readily distinguishable from other Siluriformes by the presence of a conspicuous shield-shaped rostral plate bearing numerous large and recurved odontodes (Schaefer, 2003).

Lundberg \& Baskin (1969: table 1) first cited a scoloplacid specimen as Bunocephalus sp. Bailey \& Baskin (1976) later described it as Scoloplax dicra, a new genus within the new loricariid subfamily Scoloplacinae. Isbrücker (1980) elevated Scoloplacinae to family status, thereby removing it from Loricariidae. An additional three species were described by Schaefer et al. (1989) who proposed a preliminary hypothesis of relationships within the family. Later, Schaefer (1990) produced a more detailed anatomical study and established eight synapomorphies for the family.

Field trips to Madeira and Aripuanã basins were made in 2004 and 2005 as part of the PROBIO project, and provided the first specimens of a new species of Scoloplax collected only in a small tributary of rio Aripuanã. Later, with the support of the "All Catfish Species Inventory", a third expedition was made to the Aripuanã River in 2007, producing more specimens from different localities and increasing the distribution of this new species within the Aripuanã drainage.

\section{Material and Methods}

Measurements were made to the nearest $0.1 \mathrm{~mm}$ using a digital caliper with the aid of a stereomicroscope. Body measures are given as percentages of standard length (SL) and head length (HL). Landmarks for measurements and terminology are: standard length = from tip of snout to middle caudalfin base; predorsal length $=$ from tip of snout to origin of dorsal-fin spine; head length $=$ from tip of snout to posterior margin of opercle; body width $=$ width across cleithra immediately anterior to pectoral-spine insertions; body depth = depth immediately anterior to insertion of dorsal-fin spinelet; pelvic anal distance $=$ from insertion of first pelvic-fin ray to base of first anal-fin ray; and interorbital distance $=$ least distance between bony margins of orbits. Counts of all fin rays, plates, odontodes and vertebrae were made only on cleared and stained (cs) specimens prepared according to Taylor \& Van Dyke (1985). Institutional abbreviations follow Leviton et al. (1985).

Coleção de Peixes, Instituto Nacional de Pesquisas da Amazônia, Caixa Postal 478, 69011-970, Manaus, AM, Brazil. rochainpa@yahoo.com.br; renildo@inpa.gov.br; rapp@inpa.gov.br 


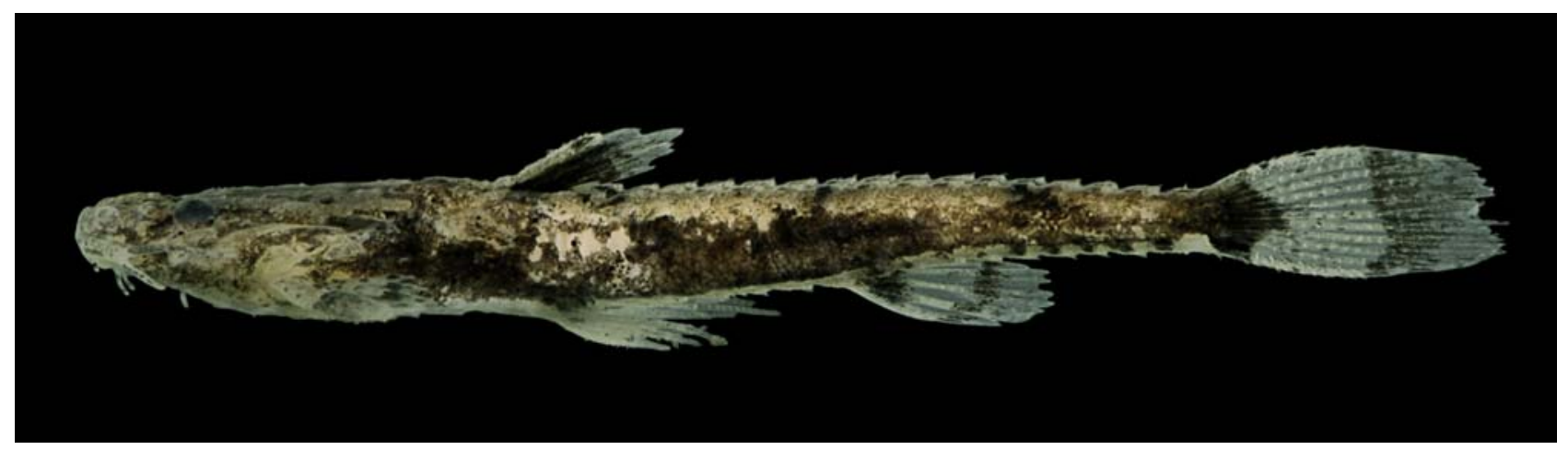

Fig. 1. Scoloplax baskini, INPA 28658, holotype, $14.4 \mathrm{~mm}$ SL. Photo by R. R. de Oliveira.

\section{Results}

\section{Scoloplax baskini, new species \\ Figs. 1-3, 4e, 5}

Holotype. INPA 28658, $14.4 \mathrm{~mm}$ SL, Brazil, Amazonas, Novo Aripuanã, rio Aripuanã, igarapé Palhalzinho, 559'32.3"S 60²12'35"W, 6 Sep 2007, L. H. Rapp Py-Daniel, M. S. Rocha \& R. R. de Oliveira. Paratypes. Brazil, Amazonas, Novo Aripuanã, rio Aripuanã drainage: ANSP 187488, 3, 12.5-13.1 mm SL, igarapé Palhalzinho, 559'32.3"S 60¹2'35"W, 6 Sep 2007, L. H. Rapp Py-Daniel, M. S. Rocha \& R. R. de Oliveira; INPA 28649, 42, (20, 11.1-17.2 mm SL; $6 \mathrm{cs}, 11.2-12.8 \mathrm{~mm} \mathrm{SL}$ ), igarapé Palhalzinho, 5059'32.3"S 60²12'35"W, 6 Sep 2007, L. H. Rapp Py-Daniel, M. S. Rocha \& R. R. de Oliveira; INPA 28650, 24, (10, 10.7-16.1 mm SL; 4 cs, 11.8-16.1 mm SL), lago do Mamão, shore, 60' $48^{\prime \prime S} 60^{\circ} 11^{\prime} 47.9^{\prime \prime} \mathrm{W}, 8$ Sep 2007, L. H. Rapp Py-Daniel, M. S. Rocha \& R. R. de Oliveira; INPA 28651, 1, $11.2 \mathrm{~mm}$ SL, igarapé da Cachoeira, just above first waterfall, close to mouth of igarapé, $6^{\circ} 24^{\prime} 39.53^{\prime \prime S} 60^{\circ} 21^{\prime} 41.06^{\prime \prime W}, 11$ Sep 2007, L. H. Rapp Py-Daniel, M. S. Rocha \& R. R. de Oliveira; INPA 28652, 29 (4 cs, not measured), igarapé Palhalzinho, 559'32.3"S 60²12'35"W, 10 Sep 2004, L. H. Rapp Py-Daniel, L.M. de Sousa \& O.M. Ribeiro; MCP 43133, 3, 10.5-13.7 mm SL, igarapé Palhalzinho, 5²59'32.3"S $60^{\circ} 12^{\prime} 35^{\prime \prime W}, 6$ Sep 2007, L. H. Rapp Py-Daniel, M. S. Rocha \& R. R. de Oliveira; MPEG 14754, 3, 12-12.3 mm SL, igarapé Palhalzinho, 559'32.3"S 60²1'35"W, 6 Sep 2007, L. H. Rapp Py-Daniel, M. S. Rocha \& R. R. de Oliveira; MZUSP 99301, 3, 12.7-14.8 mm SL, igarapé Palhalzinho, 559'32.3"S 60²'12'35"W, 6 Sep 2007, L. H. Rapp Py-Daniel, M. S. Rocha \& R. R. de Oliveira.

Diagnosis. The new species can be distinguished from other Scoloplax by the following unique features: ventral midline plates between the anus and caudal peduncle with two longitudinal parallel rows of odontodes not covered by skin; pectoral and pelvic fins with all rays simple, unbranched; larger specimens with odontodes in abdominal area between pelvic-fin bases and immediately anterior to genital papilla; mesethmoid with thickened triangular anterior process; and larger specimens with small odontodes on first and second pelvic-fin rays.
Description. Morphometrics given in Table 1. Small size, 10.5$17.2 \mathrm{~mm}$ SL. Head and body strongly depressed. Dorsal profile of head and predorsal area nearly straight except for shallow depression at posterior tip of rostral plate. Body profile straight between dorsal and caudal fins. Snout rounded in dorsal view. Head with series of odontodes forming lateral ridge from orbit to posterior pterotic-supracleithrum spine. Small bony plate located immediately lateral to lateral ethmoid and just anterior to orbit ["lateral ethmoid plate" sensu Schaefer (1990)] bearing three to five odontodes near posterior margin (Fig. 3). Rostral plate bearing 14-24 recurved odontodes. Eye dorsal and conspicuous.

Mouth small, terminal. Maxillary barbel biramous, major ramus elongate, reaching base of pectoral-fin spine; minor ramus short, not reaching base of pectoral-fin spine. Mental barbel uniramous, origin anterior to gular fold and posterior to mandibular symphysis. Mandibular barbel uniramous, origin at corner of mouth.

Small platelet at distal tip of rib on sixth vertebra bearing 3-16 small odontodes. Odontodes present on posterior coracoid process. Mesethmoid with a thickened triangular anterior process (Figs. 3, 4e). Four branchiostegal rays.

Dorsal fin with spinelet, spine and three soft branched rays. Dorsal spine with small odontodes. Locking mechanism present. Pectoral fin with well-developed spine and four unbranched rays. Pectoral spine completely covered with small odontodes and with few small serrations along posterior margin from mid-length to distal tip; locking mechanism present. Pelvic fin with four unbranched rays; first ray thicker and with odontodes. In larger specimens the second pelvic-fin ray bears a few small odontodes. Anal fin with five to six rays. First ray unbranched, thickened and bearing odontodes, followed by three to four branched rays and with the last ray unbranched. Caudal fin with 11 rays; outer rays unbranched and bearing small odontodes. Nine principal inner rays branched near tips. Procurrent caudal-fin rays absent.

Dorsolateral plates 16-17, extending posteriorly from base of last dorsal-fin ray to caudal peduncle. Ventrolateral plates 8-9. Ventral midline plates 4-6, bearing odontodes along lateral margins forming two longitudinal rows (Fig. 5). Total vertebrae $25-27(\mathrm{n}=10)$. 


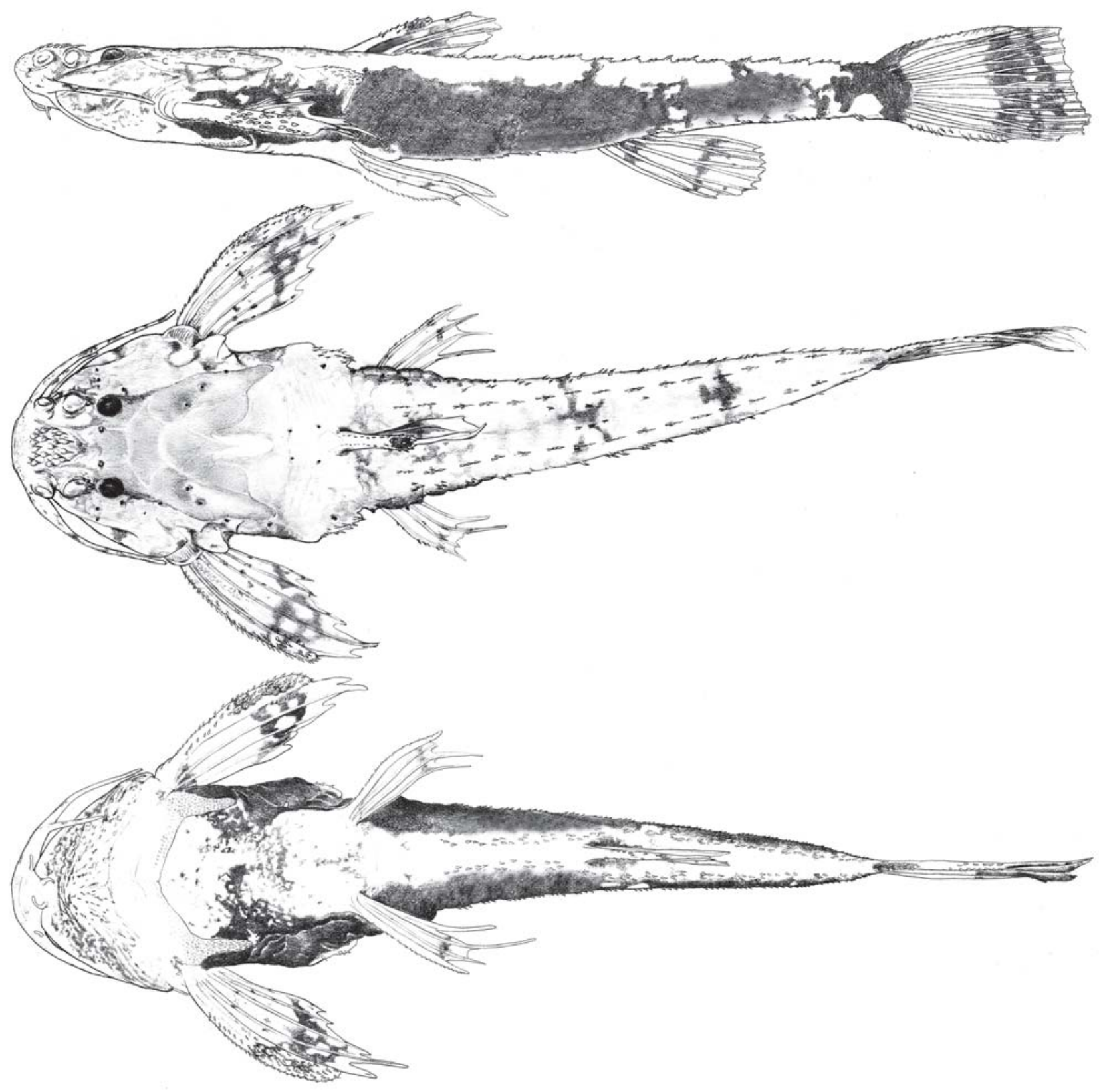

Fig. 2. Scoloplax baskini, INPA 28649, paratype, $16.3 \mathrm{~mm} \mathrm{SL}$, in lateral (top), dorsal (middle) and ventral (bottom) views. Illustration by Deyse Silva.

Coloration. Body overall brownish, more pigmented laterally with wide longitudinal dark brown stripe along lower region of trunk from pectoral to caudal fin (Figs. 1-2). Mid-ventral plate series less pigmented. Dorsal part of body pale except for three narrow dark saddles. First saddle faint, at dorsal fin origin; other two saddles darker and evenly spaced between dorsal and caudal fins. Ventral portion of body pale, creamcolored, sometimes with dark pigment concentrated along lateral edges and more diffuse pigment across abdomen. Dorsal fin darkly pigmented along base and hyaline distally. Pectoral fin largely hyaline except for dark spots clustered in spear-like submarginal band. Pelvic fin largely hyaline except for faint dark submarginal band. Anal fin with two thin dark transverse bands, one near base and the other near mid-length. Base of caudal fin with dark brown spot extending anteriorly onto caudal peduncle. Remaining caudal fin hyaline except for dark pigment forming blotchy subterminal distal band.

Distribution. Scoloplax baskini was found among leaf litter in small clearwater tributaries of the middle part of rio Aripuanã, a right-bank tributary of the middle rio Madeira (Fig. 6).

Etymology. Species name in honor of Jonathan Baskin for his significant contributions to Neotropical ichthyology including the description of the genus Scoloplax. 


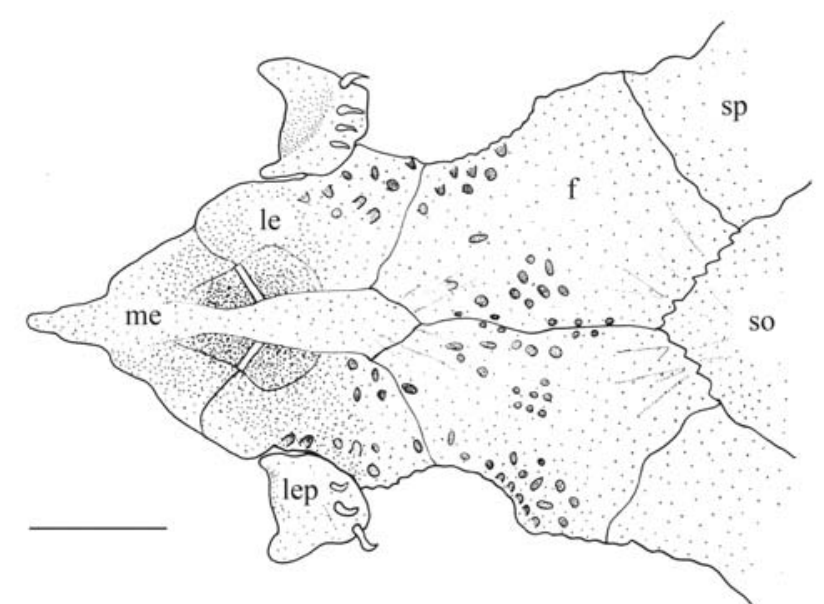

Fig. 3. Partial cranial osteology of Scoloplax baskini, INPA 28650, paratype, $16.1 \mathrm{~mm} \mathrm{SL}$, anterior toward left. Rostral plate removed. $\mathrm{f}=$ frontal; $\mathrm{me}=$ mesethmoid; le = lateral ethmoid; lep = lateral ethmoid plate; so = supraoccipital; $\mathrm{sp}=$ sphenotic. Scale $=0.5 \mathrm{~mm}$.
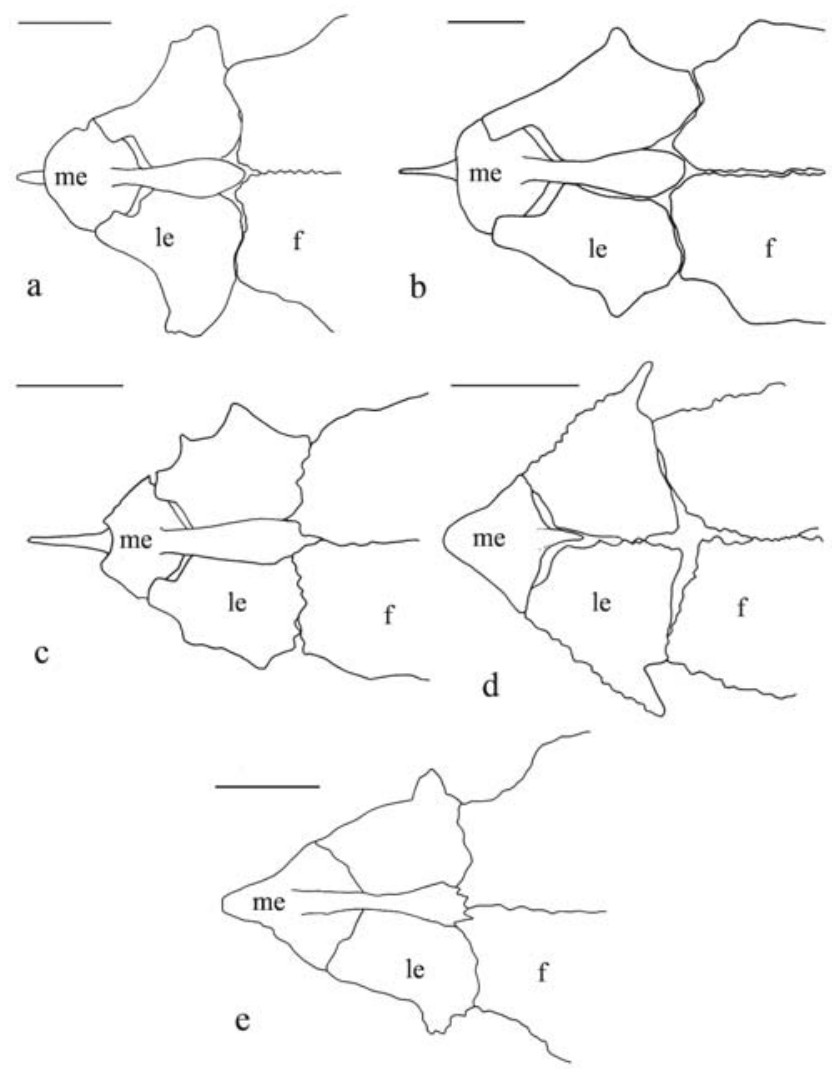

Fig. 4. Partial cranial osteology in Scoloplax. a, S. dicra; b, $S$. distolothrix; c, S. empousa; d, S. dolicholophia; e, S. baskini, INPA 28650, paratype, $11.8 \mathrm{~mm}$ SL. Anterior toward left. Rostral plate and lateral ethmoid plate removed. $\mathrm{f}=$ frontal; $\mathrm{me}=$ mesethmoid; le $=$ lateral ethmoid. Scale $=0.5 \mathrm{~mm}$. Figures a-d modified from Schaefer (1990).
Table 1. Morphometric data of Scoloplax baskini. SD = standard deviation.

\begin{tabular}{lccccc}
\hline \multirow{2}{*}{ Measurements } & \multirow{2}{*}{ Holotype } & \multicolumn{3}{c}{ Paratypes (n=31) } \\
& \multicolumn{7}{c}{ Mean } & Range & SD \\
\hline Standard length (mm) & 14.4 & 13.1 & 10.7 & 16.1 & 1.7 \\
& Percents of standard length & & & \\
Predorsal length & 36.1 & 36.9 & 28.9 & 41.1 & 2.6 \\
Head length & 20.1 & 22.2 & 16.3 & 24.6 & 1.8 \\
Body width & 29.9 & 27.8 & 21.7 & 30.9 & 2.0 \\
Body depth & 14.6 & 13.0 & 10.2 & 16.2 & 1.5 \\
Pelvic-anal distance & 25.7 & 25.8 & 19.9 & 31.7 & 2.2 \\
& Percents of head length & & & \\
Interorbital distance & 41.4 & 37.2 & 32.3 & 46.2 & 3.4 \\
\hline
\end{tabular}

\section{Discussion}

One of the diagnostic features of Scoloplax baskini is the presence of two parallel rows of odontodes on the ventral midline plates, starting posterior to vent and reaching the caudal peduncle (Fig. 5). The holotype of S. dolicholophia and conspecific specimens deposited at INPA also have two rows of odontodes on the ventral midline plates, although not clearly illustrated in Schaefer et al. (1989: fig. 10a). This feature, however, differs between the two species. In $S$. dolicholophia the rows of odontodes are largely concealed by skin with only their tips visible, whereas in S. baskini these odontodes are completely exposed and conspicuous, not skin covered.

Examination of all the species of Scoloplax (types and non-types) and the illustrations in Schaefer et al. (1989) reveal that all other Scoloplax species have at least one branched ray in the pectoral and pelvic fins. In S. baskini, both the pectoral and pelvic fins have only unbranched rays, a feature unique among Scoloplacidae.

The number of vertebrae was consistent (nonvariable) in each species analyzed by Schaefer (1990). According to Schaefer, Scoloplax dicra has 27 vertebrae (considered plesiomorphic), S. distolothrix and S. empousa have 26, and S. dolicholophia has 25. In S. baskini, however, the total number of vertebrae ranged from 25 (1 specimen) to 27 (2), with a modal value of 26 (7).

The largest specimens of Scoloplax baskini have few odontodes along the posterior margin of the pelvic girdle, between the pelvic-fin bases in the posterior abdominal area. The only other species that also has odontodes on the pelvic

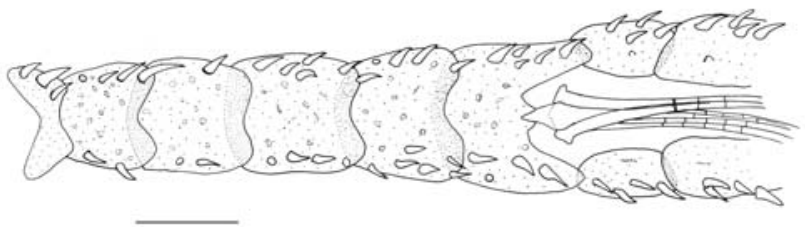

Fig. 5. Ventral midline plates in Scoloplax baskini, INPA 28650, paratype, $16.1 \mathrm{~mm}$ SL. Ventral view, anterior toward left. 
girdle is $S$. dicra. In $S$. dicra, however, the odontodes occur on two well-separated plates, whereas in S. baskini the odontodes form a row along the posterior margin of the pelvic girdle and are directly attached to this bone.

The mesethmoid midline anterior process is present and slender in Scoloplax dicra (Fig. 4a), S. distolothrix (Fig. 4b) and S. empousa (Fig. 4c), and the anterior margin of the discoid portion of the mesethmoid is either rounded (S. dicra), straight ( $S$. distolothrix) or concave ( $S$. empousa). In contrast, the mesethmoid of $S$. dolicholophia (Fig. 4d) lacks a slender anterior process (plesiomorphic condition), its anterior margin is bluntly pointed, and the entire bone has an arrow-head shape. In S. baskini the anterior process of the mesethmoid is thickened, more triangular, and has a relatively wide base (Fig. 4e), a condition somewhat intermediate between that of $S$. dolicholophia and the species that have a slender anterior process.

Scoloplax is distributed in the Amazon and Paraná/Paraguay basins. Scoloplax dicra has the largest distribution in the Amazon basin. Scoloplax empousa is known from the Amazon and Paraná/Paraguay basins, and S. distolothrix is known from rios Xingu, Tocantins, and upper Paraguay. Scoloplax dolicholophia was previously known only from the rio Negro basin (Schaefer et al., 1989). Examination of material in the INPA fish collection revealed specimens of $S$. dolicholophia collected in Lake Amanã, near the lower rio Japurá, increasing its range to sedimentary-influenced areas or "varzea" (Fig. 6).

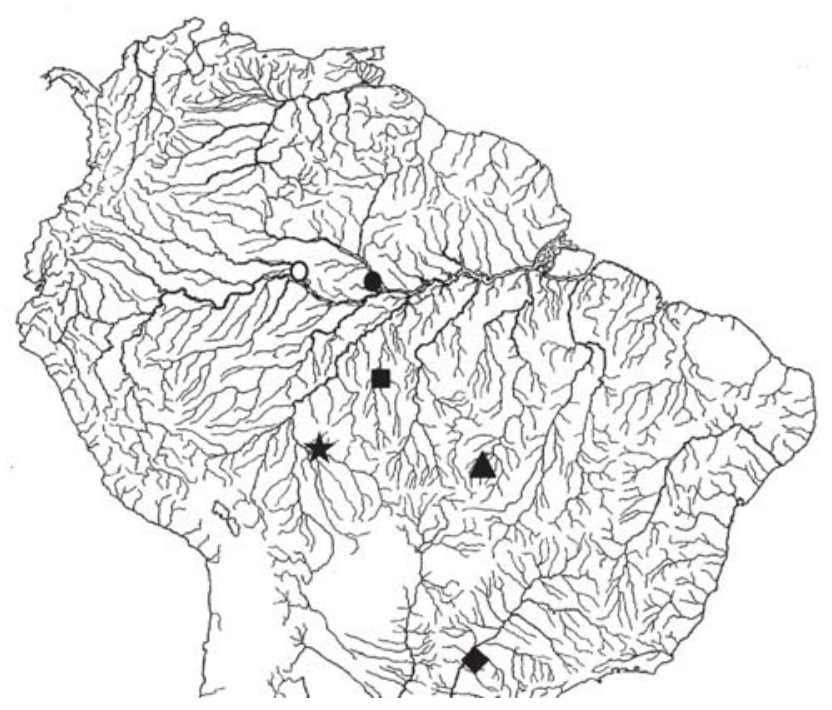

Fig. 6. Partial map of South America showing the type localities of species of Scoloplax. Square = Scoloplax baskini new species; black circle $=S$. dolicholophia; open circle $=$ new record of $S$. dolicholophia from Japurá basin; triangle $=$ $S$. distolothrix; diamond $=S$. empousa; $\operatorname{star}=S$. dicra . Base map by M. Weitzman.
Material examined. Scoloplax dicra. Brazil. Amazonas: INPA 27259, 13, Coari, rio Solimões, small tributary at right bank of igarapé Catuá. INPA 27210, 25 (4 cs), Coari, rio Solimões, igarapé Paracuba, tributary of right bank of igarapé Catuá. Scoloplax distolothrix. Brazil. Mato Grosso: MZUSP 39065, 17.9 mm SL, small trib of rio Batovi, upper rio Xingu, holotype of Scoloplax distolothrix; ANSP 162803, 10, 12.64-14.48 mm SL, same locality as MZUSP 39065, paratypes of Scoloplax distolothrix; ANSP 181058, 10, Cocalinho, Araguaia, Corixo da Saudade (Corixinho), $25 \mathrm{~km}$ NW of Cocalinho at road MT 326, tributary of rio Araguaia (Tocantins); INPA 21596, 8, rio Guaporé. Pará: INPA 4006, 51, rio Xingu, lago Arapujá, ilha de Arapujá; INPA 4159, 2, rio Xingu, ilha de Babaquara; INPA 11559, 13, rio Xingu, ilha de Babaquara; INPA 4249, 8, rio Xingu, Arroz Cru. Scoloplax dolicholophia. Brazil. Amazonas: MZUSP 6788, igarapé, tributary of rio Tarumãzinho, approximately $45 \mathrm{~km}$ north of Manaus, holotype of Scoloplax dolicholophia; INPA 4678, 1, rio Negro, Castanhal Santa Rita; INPA 28440, 36, rio Japurá, lago Amanã, Paraná do Bare; INPA 26257, 8 (2 cs), Manaus, rio Negro, igarapé Tarumã Mirim. ANSP 163461, 1, $10.22 \mathrm{~mm} \mathrm{SL}$, mouth of rio Unini, tributary to the rio Negro. ANSP 149341, 5, igarapé Aduja into rio Itu (middle rio Negro), probably opposite Barcelos. Scoloplax empousa. Brazil. Mato Grosso: MZUSP 39075, $19.94 \mathrm{~mm}$ SL, rio Ivinheima $70 \mathrm{~km}$ upstream from its confluence with rio Paraná and rio dos Bandeirantes, holotype of Scoloplax empousa. ANSP 162804, 5, 14.84-17.75 mm SL, rio Ivinheima $70 \mathrm{~km}$ upstream from its confluence with rio Paraná and rio dos Bandeirantes, paratype of Scoloplax empousa.

\section{Acknowledgments}

We gratefully acknowledge Osvaldo Oyakawa and Mário de Pinna (MZUSP) for loan of holotypes of species of Scoloplax; John Lundberg and Mark Sabaj Pérez (ANSP) for help during visit of first author to ANSP; Mark Sabaj Pérez for invaluable comments and corrections to the manuscript; Daniel Pimpão (INPA) for help on a field trip; and André Canto (INPA) for help and support at INPA. Sr. Gentil provided invaluable help as a guide and driver during the expedition to rio Aripuanã. Deyse Cristina Silva (INPA) kindly prepared illustration of Fig. 2. MSR and RRO benefited from a CNPq/ DTI scholarship as part of the institutional research program (PCI) at INPA. "All Catfish Species Inventory” Project (NSF DEB 0315963) funded the 2007 expedition and the visit of MSR to ANSP. The first expedition to rio Aripuanã was funded by MMA/MCT/CNPq Brazilian Governament and World Bank as part of the PROBIO project. This paper was greatly improved by the suggestions of two anonymous reviewers.

\section{Literature Cited}

Bailey, R. M. \& J. N. Baskin. 1976. Scoloplax dicra, a new armored catfish from the Bolivian Amazon. Occasional Papers of the Museum of Zoology University of Michigan, 674: 1-14.

Isbrücker, I. J. H. 1980. Classification and catalogue of the mailed Loricariidae (Pisces, Siluriformes). Verslagen en technische Genevens, Universiteit van Amsterdam, 22: 1-181. 
Leviton, A. E., R. H. Gibbs Jr., E. Heal \& C. E. Dawson. 1985. Standards in herpetology and ichthyology. Part 1. Standard symbolic codes for institutional resource collections in Herpetology and Ichthyology. Copeia, 1985: 802-832.

Lundberg, J. G. \& J. N. Baskin. 1969. The caudal skeleton of the catfishes. Order Siluriformes. American Museum Novitates, 2398: 1-49.

Schaefer, S. A. 1990. Anatomy and relationships of the scoloplacid catfishes. Proceedings of the Academy of Natural Sciences of Philadelphia, 142: 167-210.

Schaefer, S. A. 2003. Family Scoloplacidae (Spiny dwarf catfishes). Pp. 310-311. In: Reis, R. E., S. O. Kullander \& C. J. Ferraris, Jr. (Eds.). Checklist of the freshwater fishes of South and Central America. Porto Alegre, Edipucrs, 729p.

Schaefer, S. A., S. H. Weitzman \& H. A. Britski. 1989. Review of the neotropical catfish genus Scoloplax (Pisces: Loricarioidea: Scoloplacidae) with comments on reductive characters in phylogenetic analysis. Proceedings of the Academy of Natural Sciences of Philadelphia, 141: 181-211.

Taylor, W. R. \& G. C. Van Dyke. 1985. Revised procedures for staining and clearing small fishes and other vertebrates for bone and cartilage study. Cybium 9: 107-119.

Accepted August, 2008

Published September 30, 2008 